Revista Brasileira de Farmacognosia Brazilian Journal of Pharmacognosy 22(5): 1130-1133, Sep./Oct. 2012

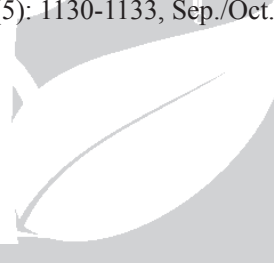

Short communication

Received 17 Aug 2011

Accepted 20 Jan 2012

Available online 12 Apr 2012

Keywords:

Felicola subrostratus

lice

control

andiroba

seeds

phytotherapy

ISSN 0102-695X

http://dx.doi.org/10.1590/S0102

$695 \times 2012005000047$

\section{In vitro efficacy of oil from the seed of Carapa guianensis (andiroba) in the control of Felicola subrostratus}

\author{
Fabíola N. de Barros," Márcia P. O. Farias, Juliana P. C. \\ Tavares, Leucio C. Alves, Maria A. da G. Faustino
}

\author{
Departamento de Medicina Veterinária, Universidade Federal Rural de \\ Pernambuco, Brazil.
}

\begin{abstract}
This study was perfomed to assess the in vitro effect of oil from the seed of andiroba (Carapa guianensis Aubl.) on Felicola subrostratus (Burmeister, 1838) (Mallophaga: Trichodectidae). Six hundred specimens of F. subrostratus from neighborhood of Jordão, Recife-PE, Brazil, were collected by hand directly from the fur of cats infested naturally. The lice were transported in plastic recipients to the Laboratory of Parasitic Diseases of Domesticated Animals of the Department of Veterinary Medicine of the Universidade Federal Rural de Pernambuco (Brazil) for the immersion test. Four dilutions of andiroba oil (100, 50, 25 and 10\%) in distilled water were tested, using Tween 80 as dispersant; two control groups (one with distilled water and the other with monosulfiram) were also formed; four replicates were performed, with 25 specimens for each dilution, totaling 100 lice per treatment. After the test, the insects were kept at room temperature and observed for mortality rates for $72 \mathrm{~h}$. The biological activity of the product achieved $100 \%$ mortality of the insects in the first hour at concentrations of 100 and $50 \%$ and in the third hour at concentrations of 25 and $10 \%$. The results demonstrate the possibility of controlling $F$. subrostratus throught the use of oil extracted from andiroba seeds.
\end{abstract}

\section{Introduction}

Lice infestation is denominated pediculosis. In cats, the etiological agent is Felicola subrostratus, which belongs to the order Mallophaga, with its characteristic pointed head This species of lice is cosmopolitan and feeds on epidermal debris and fur. Infested cats exhibit a variable degree of pruritus. This species of lice is cosmopolitan and feeds on epidermal debris and fur. Infested cats exhibit a variable degree of pruritus (Noli, 2002). Parasitism by this species of lice has been described in Brazil and other parts of the world (Pollmeier et al., 2004; Jittapalapong et al., 2008; Ferreira et al., 2009).

Transmission occurs by direct contact or contaminated brushes and combs. The fur of infected cats is often unclean, matted and has an ill appearance, as the disease is associated to the overpopulation of animals and sanitary conditions of the environment. Lice copulation occurs on the animal and females deposit their eggs, called nits, on the fur of the host. A nymph hatches from each nit and transforms into an adult. The complete cycle lasts two to three weeks. Far from the host, lice survive only a few days (Noli, 2002).

Lice infestation is generally treated with synthetic pyrethroid insecticides, carbamates, fipronil or selamectin. These drugs come in powder, liquid, shampoo, spray or spot-on form (Noli, 2002). However, plants are potential alternative to currently employed insecticides, as they are a rich source of bioactive chemical products and have both aromatic characteristics and essential oils, which are considered responsible for insecticidal activity (Carvalho, 2004). Plants constitute a viable, less aggressive treatment for cats, with less harm to ecosystems (Marinho et al., 2007).

Andiroba (or crabwood) (Carapa guianensis Aubl.) is a species of tree belonging to the family Meliaceae that is distributed throughout the northern portion of South America, including the Amazon Basin, as well as Central America, the Antilles and tropical Africa. The oil derived from andiroba seeds is used in folk medicine in northern Brazil for fever, rheumatism and as an anti-inflammatory agent, antibacterial agent and insect repellant (Neves et al., 2004).

Considering the high occurrence of parasitic dermatitis affecting domestic cats and the possibility of obtaining alternative products for combating this condition, the aim of the present study was to assess the in vitro efficacy of andiroba oil (Carapa guianensis Aubl.) on Felicola subrostratus. 


\section{Material and Methods}

The experiment was carried out at the Laboratory of Parasitic Diseases of Domestic Animals, Preventive Medicine Sector, Veterinary Medicine Department of the Universidade Federal Rural de Pernambuco (Brazil). Six hundred specimens of Felicola subrostratus were manually collected directly from the fur of naturally infected male and female domesticated cats of different ages from the neighborhood of Jordão in the city of Recife (northeastern Brazil).

The lice were transported to the laboratory in plastic recipients and divided into six treatment groups. Four repetitions were performed with 25 specimens, totaling 100 lice per treatment. An andiroba seed oil formula was obtained from Beraca Sabará SP in plastic package with $5 \mathrm{~L}$, batch $05083140 \mathrm{ST}$, rain forest RE3140. Four concentrations of the oil were tested (100, 50,25 and $10 \%$ ), using Tween 80 as the dispersant. Two other groups served as the controls, one using distilled water and the other using a conventional ectoparasiticide containing monossulfiram (Sarnasol ${ }^{\circledR}$ Schering Plough) at the concentration recommended by the manufacturer. The insects were submitted to an immersion bath in 50 $\mathrm{mL}$ disposable cups containing $3 \mathrm{~mL}$ of the respective solutions. The solution was maintained under constant agitation for three minutes, after which the excess liquid was removed and the specimens were transferred to paper-filter envelops and kept at room temperature. Six observations were made: 1, 3, 6, 24, 48 and $72 \mathrm{~h}$ after beginning the test. The assessment of efficacy was performed by counts of living and dead specimens, with mortality based on the physical aspect of the insect.

For the statistical analysis, absolute and relative distributions were determined. Pearson's chi-square test was used for comparisons between treatments, with the margin of error set at 5.0\%. The Statistical Package for the Social Sciences (SPSS, v. 15) was employed for all analyses (Zar, 1999).

\section{Results and Discussion}

Table 1 displays the percentage values of the in vitro efficacy of the oil derived from seeds of Carapa guianensis on $F$. subrostratus. One hundred percent mortality of the insects occurred within the first hour of the tests at concentrations of 100 and $50 \%$. These results were similar to those achieved with monosulfiram, which is also known as tetraethyl thiuram monosulfide. This ectotoparasiticide is a sulfur compound used by a number of researchers and has demonstrated efficacy, especially for ectoparasites of mice (Santos et al., 1988; Alexandre \& Bressnan, 1994). On cats, monosulfiram has demonstrated $100 \%$ efficacy against lynxacariosis in a study carried out in the city of Belém (northern Brazil) (Serra-Freire et al., 2002). At concentrations of 25 and $10 \%, 100 \%$ mortality of the lice occurred after three hours.

The specimens in the control group with distilled water remained viable throughout the experiment, with an increasing mortality rate beginning at $48 \mathrm{~h}$ (Table 1 ). This finding stems from the biology of the insect, which only survives two to three days without a host (Noli, 2002).

Although studies on andiroba oil as a phytotherapeutic agent are rare, the action of this oil has been demonstrated on the larvae of Musca domestica (Farias, 2007), Aedes sp. (Miot et al., 2004) and acaricidic activity has been demonstrated on ingurgitated females of Boophilus microplus (Farias et al., 2007), Anocentor nitens and Rhipicephalus sanguineus (Farias et al., 2009). In the experiment carried out by Farias (2007), larval mortality rates were $20,7.5,2.5$ and $7.5 \%$ for concentrations of 100 , 30,25 and $10 \%$ and the inhibition of the emergence of adults was demonstrated. Miot et al. (2004) concluded that

Table 1. Absolute (n) and relative (\%) frequency of specimens of Felicola subrostratus killed following immersion in solutions, according to evaluation time.

\begin{tabular}{|c|c|c|c|c|c|c|c|c|}
\hline \multirow{3}{*}{ Treatment } & \multicolumn{6}{|c|}{ Time (h) } & \multirow{2}{*}{\multicolumn{2}{|c|}{ Total }} \\
\hline & \multicolumn{2}{|c|}{ Up to 1} & \multicolumn{2}{|c|}{$>1$ to 3} & \multicolumn{2}{|c|}{$>3$} & & \\
\hline & $\mathrm{n}$ & $\%$ & $\mathrm{n}$ & $\%$ & $\mathrm{n}$ & $\%$ & $\mathrm{n}$ & $\%$ \\
\hline $100 \%$ andiroba oil & 100 & 100.0 & - & - & - & - & 100 & 100.0 \\
\hline $50 \%$ andiroba oil & 100 & 100.0 & - & - & - & - & 100 & 100.0 \\
\hline $25 \%$ andiroba oil & 80 & 80.0 & 20 & 20.0 & - & - & 100 & 100.0 \\
\hline $10 \%$ andiroba oil & 20 & 20.0 & 80 & 80.0 & - & - & 100 & 100.0 \\
\hline $2,5 \%$ monosulfiram & 100 & 100.0 & - & - & - & - & 100 & 100.0 \\
\hline distilled water & - & - & - & - & 100 & 100.0 & 100 & 100.0 \\
\hline Total group & 400 & 66.7 & 100 & 16.7 & 100 & 16.7 & 600 & 100.0 \\
\hline
\end{tabular}

*Significant difference at 5.0\%; Pearson's chi-square test between all treatments $(p<0.001 *)$; Pearson's chi-square test between 25 and $50 \%$ andiroba treatments $(p<0.001 *)$; Pearson's chi-square test between 25 and 10\% andiroba treatments $(p<0.001 *)$; Pearson's chi-square test between $10 \%$ andiroba treatment and monossulfiram $(p<0.001 *)$; Pearson's chi-square test between $25 \%$ andiroba treatment and monossulfiram $(p<0.001 *)$. 
pure andiroba oil offers a discreet repellant effect for Aedes sp., but significantly less than that offered by 50\% DEET. The in vitro tests carried out by Farias et al. (2007; 2009) achieved similar results to those of the present study, with $100 \%$ efficacy for all concentrations tested $(10,25,30,50$ and $100 \%$ ).

Studies assessing the pediculicide action of different vegetal extracts have reported lower efficacy rates than those of the present study. Neto et al. (2004) performed in vivo tests of extracts from Aspidosperma pyricollum and Anandenanthera macrocarpa for combating Damalinia caprae on goats raised in the semiarid region of the state of Paraíba (Brazil) and achieved mortality rates of $72.82-77.46 \%$ and $60.76 \%$, respectively. Heath et al. (1995) tested extracts of neem (Azadirachta indica) and pyrethum (Chrysanthemum sp.) on Bovicola ovis on sheep in comparison to conventional insecticides and obtained a reduction of 85 to $100 \%$ of the lice over a period of at least 40 to 50 days. On the other hand, Ramos et al. (2009) carried out an in vitro study on the efficacy of a solution containing extracts of Saccharum officinarum, Azadirachta indica and Eucalyptus sp. for the control of Pediculus capitis and report a $60.28 \%$ mortality rate between 3 and $6 \mathrm{~h}$ following an immersion bath, with the remaining specimens dying within $24 \mathrm{~h}$ from the beginning of the treatment, thereby demonstrating faster action in comparison to the group treated with a pyrethroid.

Substances found in vegetal extracts, such as terpenoids and alkaloids, contribute toward their activity against insects (Isman, 2000). The oil from andiroba seeds is composed nearly exclusively of saponificable material, with a high concentration of unsaturated fatty acids, such as oleic acid and palmitic acid, as well as limonoids in the non-saponificable portion, among them: andirobina, epoxiazadiradiona, $6 \alpha$-acetoxigedunina, $6 \alpha$-acetoxiepoxiazadiradiona, $6 \beta$-cetoxigedunina, $11 \beta$ acetoxigedunina, $\quad 6 \alpha, 11 \beta$-diacetoxigedunina, $\quad 6 \beta, 11 \beta$ diacetoxigrdunina, $6 \alpha$-hidroxigedunina and 7-desacetoxi7-oxogedunina, which are likely the greatest representatives of the terpene class and responsible for the insecticidal activity (Dantas et al., 2000). But despite the evidence of the bioactivity of andiroba against insects and mites, other studies must be implemented in order to assess its spectrum of action "in vivo" for treatment of ectoparasitic infestations that attack pets.

\section{References}

Alexandre SR, Bressnan MCRV 1994. Eficácia de diferentes tratamentos em cobaias (Cavia porcellus) infectadas por Chirosdiscoides caviae. Bras J Vet Res Anim Sci 13: 205-209.

Carvalho LM 2004. Efeito repelente e alelopático de plantas medicinais e aromáticas e sua aplicação na agricultura do futuro. Rev Ação Ambiental 7: 12-16.
Dantas DA, Maganha M, Beretta TE, Nozu P, Pereira GS, Matias R, Solon S, Resende U, Koller WW, Gomes A 2000. Estudo fitoquímico dos frutos de Melia azedarach L. (Cinamomo, Meliaceae). II Encontro de Pesquisa e Iniciação Científica da UNIDERP. Campo Grande, Brasil.

Farias MPO 2007. Avaliação in vivo da atividade ectoparasiticida e anti-helmíntica da andiroba (Carapa guianensis Aubl). Recife, 134 p. Dissertação de Mestrado, Programa de Pós-graduação em Ciência Veterinária, Universidade Federal Rural de Pernambuco.

Farias MPO, Sousa DP, Arruda AC, Arruda MSP, Wanderley AG, Alves LC, Faustino MAG 2007. Eficácia in vitro do óleo da Carapa guianensis Aubl (Andiroba) no controle do Boophilus microplus (Acari: Ixodidae). Rev Bras Pl Med 9: 68-71.

Farias MPO, Sousa DP, Arruda AC, Wanderley AG, Teixeira WC, Alves LC, Faustino MAG 2009. Potencial acaricida do óleo de andiroba Carapa guianensis Aubl. sobre fêmeas adultas ingurgitadas de Anocentor nitens Neuman, 1897 e Rhipicephalus sanguineus Latreille, 1806. Arq Bras Med Vet Zootec 61: 877-862.

Ferreira CGT, Bezerra ACDS, Filgueira KD, Fonseca ZAAS, Ahid SMM 2009. Levantamento de ectoparasitos de cães e gatos provenientes do município de Mossoró, Rio Grande do Norte, Brasil. Pubvet 3: 549-556.

Heath ACG, Lampkin N, Jowett JH 1995. Evaluation of nonconvencional treatments for control of the biting louse (Bovicola ovis) on sheep. Med Vet Entomol 9: 407-412.

Isman MB 2000. Pesticides based on plant essencial oils for management of plant pestis and diseases. Korea Forest Res Inst 19: 603-608.

Jittapalapong S, Sangvaranond A, Inpankaew T, Pinyopanuwat N, Chimnoi W, Kengradomkij C, Wongnakphet S 2008. Ectoparasites of stray cats in Bangkok metropolitan areas, Thailand. J Nat Sci 42: 71-75.

Marinho ML, Alves MS, Rodrigues MLC, Rotondano TEF, Vidal IF, Silva WW, Athayde ACR 2007. A utilização de plantas medicinais em medicina veterinária: um resgate do saber popular. Rev Bras Pl Med 9: 64-69.

Miot HA, Batistella RF, Batista KA, Volpato DEC, Augusto LST, Madeira NG, Haddad Jr. V, Miot LDB 2004. Comparative study of the topical effectiveness of the andiroba oil (Carapa guianensis) and DEET 50\% as repellent for Aedes sp. Rev Inst Med Trop S Paulo 46: 253-256.

Neto JOA, Almeida VF, Lima RCA, Athayde ACR 2004. Estudo etnoveterinário da ação do pereiro (Aspidosperma pyricollum Mart.) e angico (Anadenanthera macrocarpa benth, Brenan), sobre Bovicola caprae (Ewing, 1936). I Congresso de Iniciação Cientifica da UFCG, Campina Grande, Brasil.

Neves OSC, Benedito DS, Machado RV, Carvalho JG 2004. Crescimento, produção de matéria seca e acúmulo 
de $\mathrm{N}, \mathrm{P}, \mathrm{K}, \mathrm{Ca}, \mathrm{Mg}$, e $\mathrm{S}$ na parte aérea de mudas de andiroba (Carapa guianensis Aubl.) cultivadas em solo de várzea, em função de diferentes doses de fósforo. $R$ Arvore 28: 343-349.

Noli C 2002. Principais ectoparasitoses de cães e gatos. Hora Vet 21: 45-50.

Pollmeier M, Pengob G, Longob M, Jeannin P 2004. Effective treatment and control of biting lice, Felicola subrostratus (Nitzsch in Burmeister, 1838), on cats using fipronil formulations. Vet Parasitol 121: 157165.

Ramos RAN, Pimentel DS, Ramos CAN, Faustino MAG, Alves LC 2009. Eficácia do extrato concentrado contendo Saccharum officinarum L: Poaceae, Azadirachta indica A. Juss Meliaceae e Eucaliptus spp Myrtaceae, sobre Pediculus capitis De Geer, (Anoplura: Pediculidae). Rev Bras Farmacogn 19: 839-841.

Santos RO, Guaraldo AMA, Passos LAC, Rovilson G, Rangel
HA 1988. Uso do monossulfeto de tetraetiltiuram no tratamento de ectoparasitos em camundongos. Rev Saude Públ 22: 41-45.

Serra-Freire NM, Benigno RNM, Oliveira AS, Lopes LMS, Galvão G 2002. Lynxacarus radovskyi - Diagnóstico e tratamento em felinos de Belém-Pará. Rev Universidade Rural Série Ciências da Vida 22: 57-60.

Zar JH 1999. Biostatistical Analysis. 4. ed. New Jersey, USA: Prentice Hall.

\section{*Correspondence}

Fabíola N. de Barros

Departamento de Medicina Veterinária, Universidade Federal Rural de Pernambuco

Rua Dom Manoel de Medeiros, s/n, Dois Irmãos, 52171-900 Recife-PE, Brasil

fabiola.nbarros@ufpe.br 